\title{
DIFFERENCE BETWEEN TWO INBRED STRAINS OF MICE IN OVULATORY RESPONSE TO REPEATED ADMINISTRATION OF GONADOTROPHINS
}

\author{
TEH PING LIN AND DONALD W. BAILEY \\ Department of Anatomy and Cancer Research Institute, \\ University of California Schcol of Medicine, San Francisco, California, U.S.A.
}

(Received 20th April 1965)

\begin{abstract}
Summary. From one to ten superovulations were induced in 116 $\mathrm{BALB} / \mathrm{c}$ and $123 \mathrm{C} 57 \mathrm{BR}$ inbred mice by injections of pregnant mare's serum and human chorionic gonadotrophin at intervals of 4 days, 1 week or 2 weeks. It was found that (1) repeated superovulation elicited a refractoriness to the gonadotrophins which was attained more quickly and more strongly in BALB/c mice than in C57BR mice, (2) that this refractoriness was probably developed toward human chorionic gonadotrophin rather than to pregnant mare's serum and (3) that mating could stimulate ovulation in hormone-primed mice which were refractory after ten successively repeated superovulations.
\end{abstract}

\section{INTRODUCTION}

Egg production in mammals is usually diminished if ovulation is induced repeatedly by gonadotrophin in the same donor. This phenomenon is illustrated by the sequential decline in the number of corpora lutea in the course of six successive superovulations in the cow (Willett, Buckner \& McShan, 1953) and by a decrease in the number of eggs liberated after two successive superovulations in the mouse (Edwards \& Fowler, 1960). Little is known about the cause or nature of the refractoriness although it has been suggested that it is due to an immune reaction (Thompson, 1941).

The present study was undertaken to examine the effect of repeated administrations of gonadotrophins in mice of two inbred strains, to assess differences in egg production when the gonadotrophins were employed at different intervals of time, and to determine whether the two strains differed significantly in their response to the repeated administration of gonadotrophin.

\section{MATERIALS AND METHODS}

One hundred and sixteen BALB/c and 123 C57BR female mice, aged about 2 months at the time of the first induced ovulation, were used. Three groups of mice from each strain received identical treatment except for the interval between successively induced ovulations. Ovulation was induced in the first group every 4 days, in the second group every week and in the third group every 2 weeks. 
Ovulation was induced by the following procedure: $72 \mathrm{hr}$ before the desired time of ovulation the mice were each given an intra-peritoneal injection of three international units (i.u.) of pregnant mare's serum (PMs; Equinex, Ayerst); $59 \mathrm{hr}$ later an intra-peritoneal injection of 6 i.u. of human chorionic gonadotrophin (HGG; APL, Ayerst) was administered. Thirteen to fourteen hr after HCG injection, the mice were killed, their oviducts transferred to normal saline in a depression slide and the distended tubal ampullae excised; the released eggs were then counted under a dissecting microscope. Ovaries from mice of each ovulation category were prepared for histological examination.

After the tenth induced ovulation, a total of sixteen randomly chosen mice were mated with normal males at the time when their counterparts were killed. Fourteen of these mice were killed $5 \mathrm{hr}$ later and their oviducts examined for eggs; two C57BR females of the 4-day interval group were allowed to go to term for a preliminary test of their ability to maintain pregnancy.

\section{RESULTS}

In general, the study indicates that the number of eggs produced by either strain declined with repeatedly induced ovulation and that the two inbred strains differed significantly from each other in their ovulatory response to the injected gonadotrophins. The data are detailed in Table 1 which shows the average number of normal eggs counted per mouse throughout the series of induced ovulations (designated by Roman numerals) for the two strains and the three interval groups. These data are presented in Text-fig. 1 ( $a$ and b), with a regression line drawn for each of the groups.

The homogeneity of the egg counts of the first ovulation in all groups was tested for both strains by the analysis of variance. The between interval-group source of variance was not significant within either strain; therefore, we concluded that all began their treatment on an equal basis. The two strains differed, however, in that BALB/c females began with a lower average egg count than did the C57BR females, respectively 10.9 and 16.2 . This difference was significant at the $5 \%$ level.

For both strains, the overall egg count declined in all three interval groups. In the 4-day interval groups, the slopes of the regression lines for eggs ovulated by the two strains were similar (Text-fig. 1). However, for both the 1-week and 2-week interval groups, the slopes of the regression lines were very different for the two strains (Text-fig. 1). From an average of 10.9 eggs at the first ovulation, the number of eggs produced by the BALB/c females had dropped to zero by ovulation $\mathrm{V}$. No subsequent injection of gonadotrophins produced ovulation in this strain after the refractoriness was attained (Table 1; Text-fig. 1). In contrast, the C57BR mice started with a high egg count (average 16.2) which declined gradually. However, some eggs were still produced by the C57BR females even after the tenth induced ovulation. Five of seventy-eight C57BR mice failed to ovulate during the first seven efforts at superovulation while eight out of thirty-five C57BR females produced no eggs at all during the last three attempted ovulations (VIII to X) thereby accounting for the low mean values shown in Table 1 . Six of the eight unovulated C57BR mice belonged to the 4-day interval group and two to the 1-week group. 


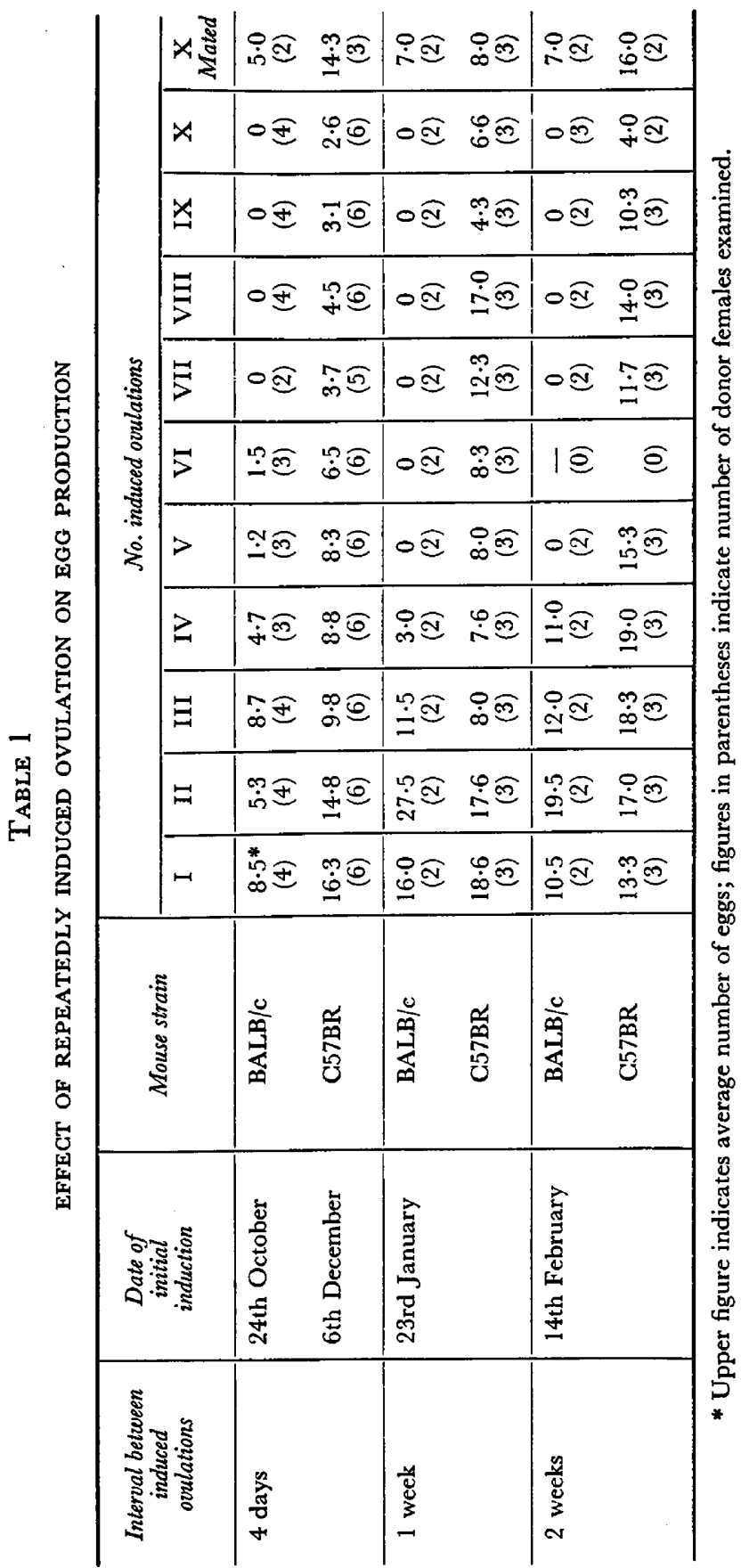


The strains thus differed in two respects: in egg count at the first induced ovulation and in the rate at which egg production became refractory. In addition, a higher average number of eggs were produced at the second than at the first ovulation in the 1- and 2-week interval animals of the BALB/c strain; however, this 'rise' at second ovulation was followed by a decline to no eggs at attempted ovulation $\mathrm{V}$ as noted above.

Many degenerated eggs without cumulus and coronal cells were found along with normal appearing eggs in several instances in the C57BR strain, namely,

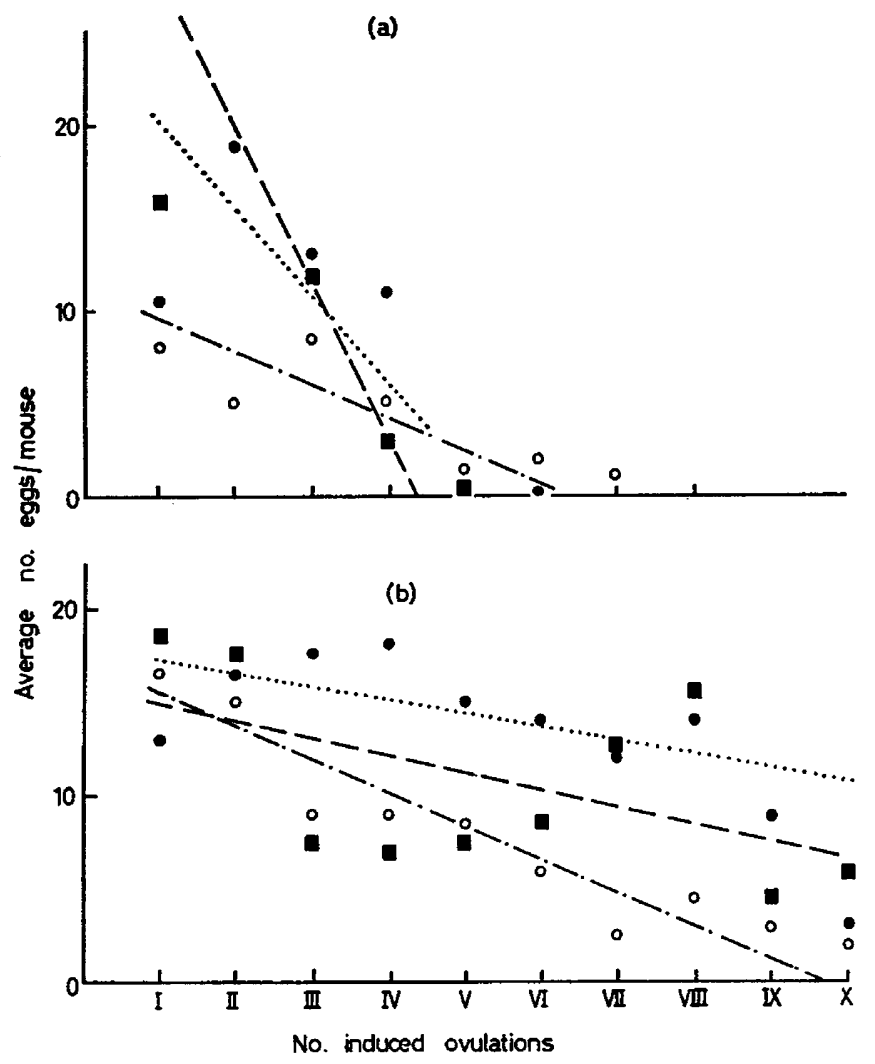

TEXT-FIG. 1. Average number of eggs in ampullae of each mouse after ovulations induced at different intervals. Mean values and their regression lines are depicted for the different intervals. (a) BALB/c mice; (b) C57BR mice. O- - - - - - , 4-day interval; a- - , 1-week interval; $9 . \cdots . . . . . . . . . . . ., 2$,week interval.

for ovulation VI of the 1-week interval group and ovulations VIII and IX of the 2-week interval group; they were not found in the case of the BALB/c strain. Such eggs may have come from spontaneous ovulations occurring between the induced cycles; they were not observed in the 4-day group nor in the early ovulations and are not included in the data presented in Table 1 or Text-fig. 1 .

The final column of Table 1 shows the number of eggs produced in the fourteen mice which had undergone ten induced ovulations and which were then mated with normal males at the time their counterparts were killed for egg 
PLATE 1

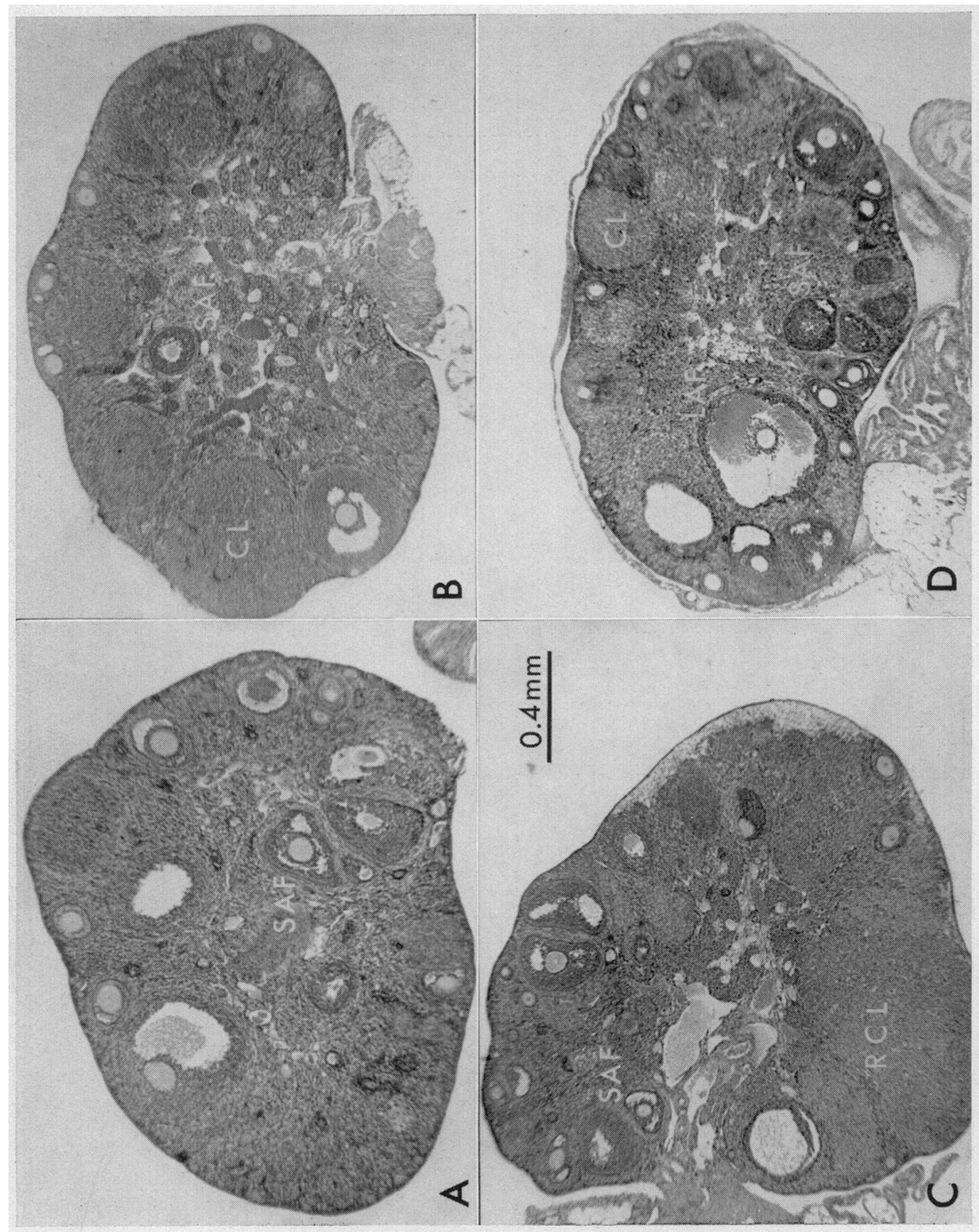

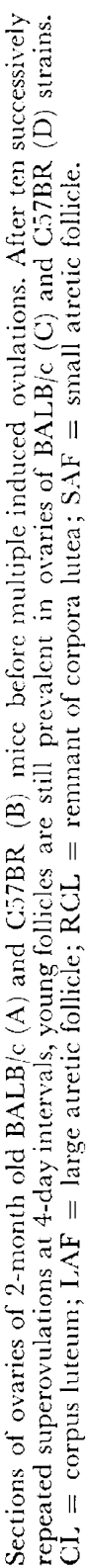

(Facing p. 256) 
counts. Five hours after vaginal plugs were found, these animals were autopsied and the number of liberated ova determined. As seen in Table 1, the mated mice showed no drop in egg production and the number of eggs discharged were comparable to those of the initial ovulation. This liberation from the refractory state was most apparent in the BALB/c mice. Two extra C57BR females in which ovulation had br $n$ induced on ten successive occasions at 4-day intervals were mated $w_{\star}$ n fertile males 13 to $14 \mathrm{hr}$ after the last HCG injection, then were isolated an "ieir pregnanries allowed to go to term. One female delivered a litter of five in 21 days; the other a litter of seven in 24 days. The longer gestation time of the second female may have resulted from developmental arrest or delayed implantation (Smithberg \& Runner, 1960); in each case the young appeared normal.

Microscopic examination of ovaries from uninjected mice of both strains revealed growing follicles usually lying immediately beneath the tunica albuginea. Before induced ovulation more corpora lutea were found in the $\mathrm{C} 57 \mathrm{BR}$ than in the BALB/C mice (PI. 1, A and B) but after repeated superovulation the number of corpora lutea increased in both strains; preovulatory swelling of follicles was occasionally encountered and follicular atresia occurred frequently. However, after ovulation $\mathrm{X}$, the majority of follicles still appeared normal and some growing follicles reached the stage of functional maturity; they were located mostly at the periphery of the ovary although a few were deep within the organ (Pl. 1, C and D). Some growing follicles were always present in the ovaries of animals in which ovulation had been repeatedly induced.

\section{DISCUSSION}

Histological findings demonstrate that oocytes and growing follicles are present in the ovaries even after ten successive superovulations. Although some instances of atresia of younger follicles was observed, probably due to gonadotrophin treatment (Hisaw, 1947), such follicular death cannot fully account for the development of refractoriness to repeated induced ovulation since abundant oocytes are still present in the ovaries. It is concluded that the eventual failure of ovulation in this experiment was not entirely due to follicular atresia by gonadotrophins nor to exhaustion of oocytes from the ovary.

Whether the decline in ovulation resulted from delay in the time of initiation of egg release, a retarded ovulation rate, or a complete blockage of ovulation, cannot be determined with certainty. From other experiments with thirty-six $\mathrm{BALB} / \mathrm{c}$ females, it was found that there is no apparent difference between egg counts at $14 \mathrm{hr}$ and $20 \mathrm{hr}$ after HCG injection; therefore, had there been a shift in time of ovulation it would have occurred after the count at $20 \mathrm{hr}$; further, ovulation could not have been shifted to the extent that eggs already discharged would have been included in the next ovulation, for then denuded or normal eggs would have been found in the refractory BALB/c females, and this never occurred. The histological observations and the ovulation of refractory females after mating indicate that the eventual refractoriness of ovulation encountered was due to eggs maturing but failing to be released.

Although a relationship between age and hormone response has been shown 
in the rabbit (Beatty, 1958) and in the rat and mouse (Zarrow \& Wilson, 1961), the decline in egg production after repeated superovulations apparently was not due to the increase in age of the females, as the refractory animals produced eggs when mated after ovulation X (Table 1).

Observations are consistent with the hypothesis that refractoriness is due to antibody formation against the injected hormones, although actual proof is lacking. The steep slope of the BALB/c regression lines for the long interval groups as compared with that for the 4-day interval group (Text-fig. 1), indicates that refractoriness in these mice is a function of time, a characteristic of an immune reaction. Moreover, the $\mathrm{BALB} / \mathrm{c}$ females achieved a more refractory state at a more rapid rate than did the C57BR animals and it has been shown (Fink \& Quinn, 1953; Ipsen, 1959) that BALB/c mice are generally more efficient antibody producers than are other strains of mice.

Refractoriness was attained slowly, if at all, by C57BR females in the longer interval groups. Even in this strain, however, when the hormone preparations were given repeatedly at 4-day intervals, a marked decline in egg production occurred. If an antihormone hypothesis is correct, the more frequent hormone injections may then have provided enough antigen, both in frequency and amount, to stimulate antihormone formation.

The data also suggest that refractoriness was developed against HCG rather than against PMs. Since mating caused ovulation in repeatedly superovulated, refractory mice and since mature follicles were present in sections of their ovaries, it is apparent that the follicles were primed for ovulation but that oocytes were not released from them. This does not necessarily mean that no antibody to PMs was elicited, as in the finch (Witschi \& Johnson, 1960) antibodies are formed against injected PMS but are not effective in reducing the hormone activity of subsequently injected PMS.

The fact that mating was sufficient to cause egg release implies that ovulation can be stimulated in the mouse in a manner similar to that in the rabbit and the rat (Dempsey \& Searles, 1943).

\section{ACKNOWLEDGMENT}

Part of the data presented was collected from the mouse colony at the American Foundation for Biological Research, Madison, Wisconsin. We are indebted to Dr U. D. Sharma for participating in the initial phase of this experiment and express our thanks to Doctors W. O. Reinhardt, W. R. Lyons, I. W. Monie, L. E. Glass and A. H. Gates for helpful suggestions. Photographs were made by Mr D. R. Akers.

\section{REFERENCES}

BEATtY, R. A. (1958) Variation in the number of corpora lutea and in the number and size of 6-day blastocysts in rabbits subjected to superovulation treatment. F. Endocrin. 17, 248.

DempSEY, E. W. \& SeARLES, H. F. (1943) Environmental modification of certain endocrine phenomena. Endocrinology, 32, 119.

EDWARDs, R. G. \& Fowler, R. E. (1960) Superovulation treatment of adult mice; their subsequent natural fertility and response to further treatment. F. Endocrin. 21, 147.

Frnk, M. A. \& Quins, V. A. (1953) Antibody production in inbred strains of mice. F. Immunol. 70, 61. Hisaw, F. L. (1947) Development of Graafian follicles and ovulation. Physiol. Rev. 27, 95.

IPSEN, J. (1959) Differences in primary and secondary immunizability of inbred mouse strains. $\mathcal{F}$. Immunol. 83, 448. 
Smithberg, M. \& RUNner, M. N. (1960) Retention of blastocysts in nonprogestational uteri of mice. 7. exp. Zool. 43, 21.

Thompson, K. W. (1941) Antihormones. Physiol. Rev. 21, 588.

WILLETt, E. L., BuCKNeR, P. J. \& McShan, W. H. (1953) Refractoriness of cows repeatedly superovulated with gonadotrophins. F. Dairy Sci. 36, 1083.

Wrrschr, E. \& Johnson, D. C. (1960) Effect of repeated PMs injections in the weaver finch. Anat. Rec. 137,401 .

Zarrow, M. X. \& Wilson, E. D. (1961) The influence of age on superovulation in the immature rat and mouse. Endocrinology, 69, 851. 